\title{
REAKTÍV PLAZMAPORLASZTÁSI FOLYAMAT FELÜGYELETI ÉS ADATGYÛJTŐ RENDSZERÉNEK KIALAKÍTÁSA
}

\section{DEVELOPMENT OF A MONITORING AND DATA ACQUISITION SYSTEM FOR THE REACTIVE PLASMA SPUTTERING PROCESS}

\author{
Fekete Albert-Zsombor ${ }^{1,2}$ \\ ${ }^{1}$ S.C. Tetronic S.R.L., 547530, Románia, Marosszentgyörgy, Wesselényi Erzsébet ut- \\ ca 6 szám; Tel. +40-766-649950, zsombor.fekete@,tetronic.ro \\ ${ }^{2}$ Sapientia - Erdélyi Magyar Tudományegyetem, Marosvásárhelyi Kar, 540485, \\ Románia, Marosvásárhely, Segesvári út 1C; Tel. +40-766-649950;
}

\begin{abstract}
One of the key tasks in the automation of the reactive magnetron plasma sputtering process is the data management and the development of a monitoring system. The study presents in detail the implementation of a particular multi-level monitoring system, the classification method of the various measurements, the selection of different backup frequencies, the integration of cloud type data servers with redundant backup and optimized usage, as well as the different methods used to access the system remotely with specific user rights and restrictions.
\end{abstract}

Keywords: monitoring system, network, data management, cloud, remote access

\section{Összefoglalás}

A reaktív magnetronos plazmaporlasztási folyamat automatizálásának egyik meghatározó feladata az adatmenedzsment és a felügyeleti rendszer kidolgozása. A tanulmány részletesen kitér a sajátos, többszintes felügyeleti rendszer megvalósítására, a különböző mérési eredmények osztályozásának módjára, a különböző mentési frekvenciák megválasztására, felhő típusú adatszerverek redundáns adatmentésének integrálására és optimalizált felhasználására, valamint adott felhasználói jogok és korlátozások mellett a rendszerek távolról történő hozzáférésére alkalmazott módszerekre.

Kulcsszavak: felügyeleti rendszer, hálózat, adatmenedzsment, felhö, távoli hozzáférés

\section{Bevezető}

A különféle ipari és laboratóriumi feltételek mellett lezajló folyamatok megismételhetőségének egyik alapköve-telménye a paraméterek megfelelő szabályozása mellett a mérési adatok és rendszerállapotok mentése. Ezen tárolt adatok utólagos kiértékelése, feldolgozása nagymértékben hozzájárul a tanulmá-nyozott folyamat során észlelt jelenségek feltérképezéséhez, valamint a megjelenő hibák kiküszöböléséhez.

Jelen tanulmány célja a Sapientia Erdélyi Magyar Tudományegyetem Marosvásárhelyi Karán müködő Vékony-réteg Fizika Kutatólaboratórium reaktív magnetronos plazmaporlasztási berendezése számára kialakított felügyeleti rendszer bemutatása. 
A kitüzött cél tehát egy adatcsere céljából kialakított egységesített kommunikációs kapcsolat biztosítása a használt, Ethernet alapú hálózatra csatlakoztatott valamennyi eltérő architek-túrájú mérő és szabályozó berendezés között.

\section{Kísérleti berendezés}

A porlasztó berendezés felépítésében szereplő mérő és beavatkozó rendszerek egy, az iparban is megjelenő háromszintes (felhasználói, irányítási és folyamatközeli) hierarchikus rendszerbe szerveződnek [2].

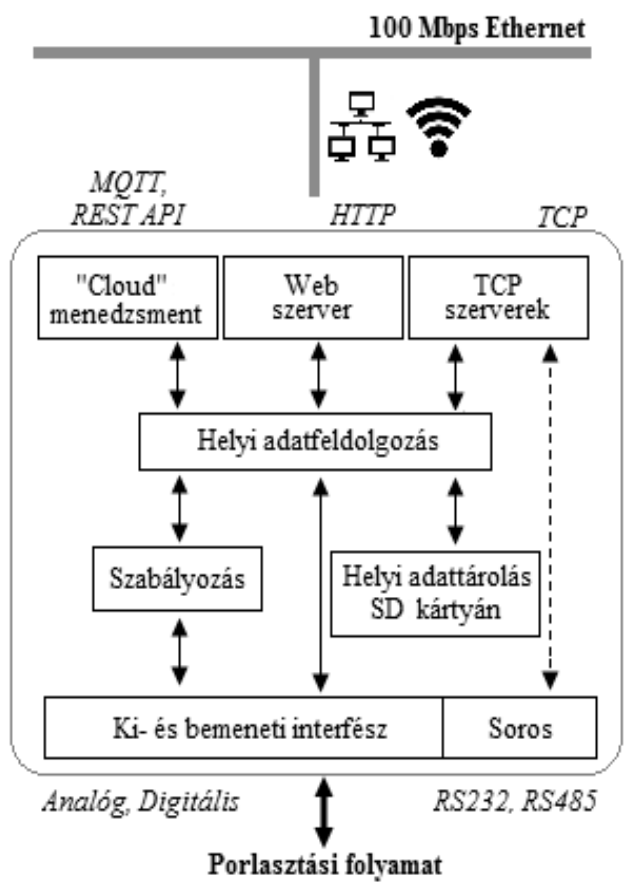

1. ábra. A porlasztási folyamat beágyazott irányitási rendszerének egyszerüsitett tömbrajza

Az irányítási rétegben többnyire saját fejlesztésű osztott beágyazott rendszerek és meglévő berendezések számára készített hálózati interfészek szerepelnek. Bár elektronikai és számítástechnikai szempontból jelentősen eltérő architektúrával rendelkeznek, a két típusú eszköz a hálózati szolgál- tatások (Web szerver, TCP szerver(-ek) és kliens(-ek), adatszerverrel való kapcsolattartás) és müködés (helyi adatfeldolgozás és tárolás, szabályozás) szempontjából megegyezik (1. ábra).

Kevésbé számításigényes feladatok implementálására többnyire ESP8266-os vezeték nélküli (WiFi) hálózati kapcsolatra alkalmas modul segítségével fejlesztett beágyazott rendszereket alkalmazunk. Ilyen például a különbözö aszinkron soros (RS232, RS485) és TCP üzenetátjátszók (pl. Pfeiffer Vacuum TPG261-PKR251 típusú nyomásmérö, optikai spektrumanalizátor, a mintatartó hőmérsékletmérője, a polarizációs feszültségmérö), valamint az állapotfigyelők (pl. hütési feltételek megléte hozamkapcsolók és hőmérsékletérzékelők révén).

Ezzel szemben a szabályozási feladatok elvégzésére (pl. dinamikus nyomásszabályozó [2], a használt reaktív gázok parciális nyomásainak mérésére, valamint a gázelegy összetételének meghatározására használt quadrupól típusú tömegspektrométer vezérlése [1]) egy PIC32MX795F512L és dsPIC33FJ128MC706 mikrovezérlökre alapozott, vezetékes hálózati kapcsolatra alkalmas osztott beágyazott rendszert fejlesztettünk [1].

\section{Adatmenedzsment}

$\mathrm{Az}$ adatmenedzsment tulajdonképpen két részre bontható: adatfeldolgozás és adatmentés. A gyors és lassú szabályozási hurkok révén, az adatfeldolgozás úgy az irányítási (beágyazott rendszerek), mint a felhasználói szinten (felügyeleti rendszer) jelen van.

$\mathrm{Az}$ adatmentés szerves része a porlasztási folyamat automatizálásának, és ahogyan a 2. ábrán is megfigyelhetjük, három szinten valósul meg:

- „Felhő” típusú adatszerverek szintjén;

- a felhasználói szinten (helyi tárolás);

- az irányítási szinten (helyi tárolás). 


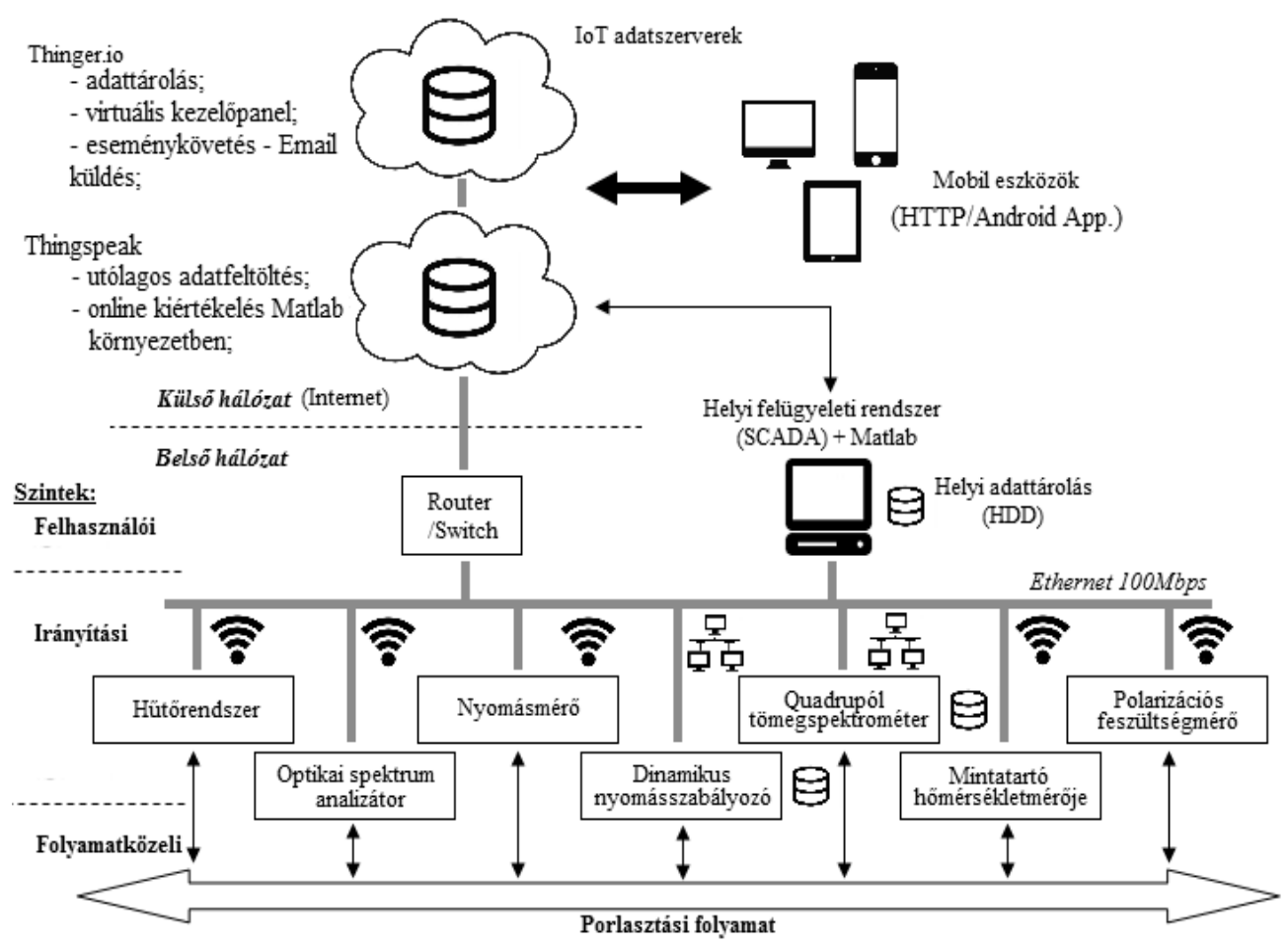

2. ábra. Adatmenedzsment megvalósitása a reaktív plazmaporlasztási folyamat többszintes automatizált rendszere esetében.

Fentről lefele haladva nő a mentési frekvencia, azonban csökken az adatmennyiség és a rendelkezésre álló tárhely, valamint a tárolt adatok távolról történő elérésének lehetősége. Az utóbbi csak a külső adatszerverek révén valósul meg.

A mentési frekvenciát mindig az adott szinten rendelkezésünkre álló tárhely mérete és a hozzáférési-idő határozza meg. Ennek eredményeképpen a beágyazott rendszerek szintjén rendszerint nagy felbontású, 50ms-os mentési periódusú lokális adatmentés történik SD memória-kártyára.

\subsection{Helyi felügyeleti rendszer}

A helyi felügyeleti rendszer egy grafikus kezelőfelülettel rendelkező, CVI Labwindows környezetben fejlesztett alkalmazás, amely teljes körü hozzáférést biztosít a rendszerhez. Ezen szolgáltatás kizárólag a belső hálózaton keresztül érhető el az előre meghatározott portok és a kommunikációs protokoll [2] ismeretében. A felügyeleti rendszer alapfunkciói közé sorolhatjuk továbbá az adatfeldolgozást, adatmegjelenítést, valamint a háttértárolóra történő adatmentést. A rögzített $250 \mathrm{~ms}-\mathrm{os}$ mentési periódussal tárolt rendszerparaméterek kiegészülnek egy kétbites adatmezővel, amely az adott érték állapotát jelzi $(0$ - érvényes adat, 1 - megszakadt hálózati kapcsolat, 2 - hibás érzékelő). Ezen eljárás segít a mentett adatok helyességének ellenőrzésében.

\section{2. „Felhő” típusú adatszerverek}

Mivel a felhasználói szinten lévő számítógépes felügyeleti rendszer az előkészületi 
fázisban (pl. vákuum feltételek biztosítása, mintatartó felfütése) nem üzemel, ezért szükségessé vált egy magasabb szinten történő adatarchiválás megvalósítása. Napjainkban már számos lehetőség áll a rendelkezésünkre a távoli hozzáférés és adatmentés biztosítására a Tárgyak Internetének (Internet of Things - IoT) köszönhetően [3,4].

Redundancia végett, két különálló adatszervert vettük igénybe: Thinger.io [3] és Thingspeak [4]. Az első IoT szerver legfontosabb szolgáltatásai:

- adott eseményre (hibaállapot kiala-kulása vagy napi kimutatás) történő változtatható tartalmú Email küldése;
- tárolt adatok kívánt időintervallum szerint történő lekérdezése/letöltése;

- adatmentés és megjelenítés testreszabható virtuális kezelőpanel kialakí-tásának lehetőségével (böngésző és dedikált applikáció révén is elérhetö).

A második adatszerver lehetőséget nyújt a tárolt adatok Matlab környezetben történő online kiértékelésére és feldolgozására [4].

\section{Mérési eredmények}

Az 1. táblázat három beágyazott eszköz különböző szintekre vonatkozó adatmentési beállításait tartalmazza.

1. táblázat. Különbözö szintekre vonatkozó adatmentési beállitások

\begin{tabular}{|c|l|c|c|c|c|}
\hline \multirow{2}{*}{ Eszköz } & \multirow{2}{*}{ Adattípus } & \multicolumn{2}{|c|}{$\begin{array}{c}\text { Helyi adattárolás (adatmeny- } \\
\text { nyiség/mentési periódus) }\end{array}$} & \multicolumn{2}{|c|}{$\begin{array}{c}\text { IoT adatszerverek } \\
\text { (adatmennyiség/mentési } \\
\text { periódus) }\end{array}$} \\
\cline { 3 - 6 } & & Eszköz & $\begin{array}{c}\text { Felügyeleti } \\
\text { rendszer }\end{array}$ & Thinger & Thingspeak \\
\hline $\begin{array}{l}\text { Dinamikus nyomás- } \\
\text { szabályozó }\end{array}$ & Paraméterek & $8 \mathrm{~B} / 100 \mathrm{~ms}$ & $30 \mathrm{~B} / 250 \mathrm{~ms}$ & $5 \mathrm{~B} / 1$ perc & $5 \mathrm{~B} / 20 \mathrm{~s}$ \\
\hline \multirow{2}{*}{ Tömegspektrométer } & $\begin{array}{l}\text { Parciális nyo- } \\
\text { mások }\end{array}$ & - & $160 \mathrm{~B} / 250 \mathrm{~ms}$ & - & - \\
\cline { 2 - 6 } & Gázösszetétel & - & $4 \mathrm{kB} /$ pásztázás & - & - \\
\cline { 2 - 6 } & Paraméterek & $10 \mathrm{~B} / 50 \mathrm{~ms}$ & $10 \mathrm{~B} / 250 \mathrm{~ms}$ & $5 \mathrm{~B} / 2 \mathrm{perc}$ & $10 \mathrm{~B} / 20 \mathrm{~s}$ \\
\hline Nyomásmérö & Nyomás & - & $5 \mathrm{~B} / 250 \mathrm{~ms}$ & $2 \mathrm{~B} / 1$ perc & $2 \mathrm{~B} / 20 \mathrm{~s}$ \\
\hline
\end{tabular}

\section{Következtetések}

Az elért eredmények alapján elmondható, hogy a bemutatott rendszer hozzájárul a porlasztási folyamat megismételhetőségének biztosításához és az alkalmazott redundanciák révén csökkenti az adatvesztés esélyét. Ugyanakkor megfelelő hozzáférési jogok mellett az automata berendezés müködése a világ bármely pontjáról felülvizsgálható.

\section{Köszönetnyilvánítás}

Köszönet illeti Kelemen András, Bíró Domokos, Jakab-Farkas László és Szöllösi István urakat a bemutatott felügyeleti, mérő és irányítási rendszer elkészítése során nyújtott nélkülözhetetlen segítségükért.

\section{Szakirodalmi hivatkozások}

[1] Fekete, A.Zs., Jakab-Farkas, L.: Development of an embedded system for accessing mass spectrometry measurements through ethernet network, Proceedings of the XXI ${ }^{\text {th }}$ International Scientific Conference of Young Engineers, Cluj-Napoca, Romania, 17-18 March 2016, pp. 161-164.

[2] Fekete, A.Zs.,: Automation of the reactive magnetron sputtering process. Proceedings of the XVII ${ }^{\text {th }}$ International Scientific Conference of Technical Sciences, Cluj-Napoca, Romania, November 2016.

[3] https://thinger.io/ (2017).

[4] https://thingspeak.com/ (2017). 